\title{
EU STRUCTURAL SUPPORT AND ITS IMPACT ON LITHUANIA'S PROGRESS
}

\author{
Rima Tamošiūniené $\dot{1}^{1}$, Skirmantas Šidlauskas² ${ }^{2}$ Ingrida Trumpaité \\ Vilnius Gediminas Technical University, Saulètekio al. 11, LT-10223 Vilnius, Lithuania \\ E-mail: ${ }^{1}$ rimtam@vv.vgtu.lt; ${ }^{2}$ skirmis@sala.lt; ${ }^{3}$ Ingrida.Trumpaite@vv.vgtu.lt \\ Received 7 May 2007, accepted 15 June 2007
}

\begin{abstract}
During the last years the changes of social - economic situation have been fast, however, according to individual macroeconomic indexes Lithuania is still significantly below the average of EU countries. To decrease these discrepancies the EU grants the structural support, the use of which is anticipated to establish strong and competitive economy, to train qualified labour force and stimulate social and economic cohesion. The efficient and expedient use of the EU support would enable Lithuania to implement the national Lisbon strategy programme and contribute to the implementation of the very Lisbon strategy guidelines. However, the investigations showed that the use of the support is not sufficient enough to secure the efficient progress of the country.

The article analyses the aspects of the EU regional policy financing and the expected results of implementing the Lisbon strategy actions; it analyses economic, social, environmental, and other indexes of the economies of Lithuania and EU countries and assesses the result of the country's progress in implementing the Lisbon strategy. The research on the expedience of using the EU structural support and its impact on the country's progress was carried out.

The research made on the use of the EU support and its impact on the country's progress suggests that about two thirds of the measures correspond to the national programme for implementing the Lisbon strategy but only few indicators have a complex influence on the progress indexes. Therefore, while preparing the programmes of the EU support use for 2007-2013 and coordinating them with the EU Commission a better harmonization of this support use measures with the national programme for implementing the Lisbon strategy is necessary, and the measures have to be implemented in a complex manner, as well as the horizontal compatibility of the measures has to be maintained.
\end{abstract}

Keywords: EU structural support, Lisbon strategy, progress indexes.

\section{Introduction}

At present, the changes of social - economic situation are fast, however, according to individual macroeconomic indexes Lithuania is still significantly below the average of EU countries. The Lithuanian GNP makes only $52 \%$ of the EU countries' average, unemployment has decreased rapidly during recent years but the efficiency of employees is only $52,5 \%$ of the EU average and the people employed in agriculture, hunting and forestry accounts for $13,9 \%$ of all labour force (EU average is 5,8\%). It has been provided in the EU Treaty that the European Community must try to decrease differences in the development level between different regions and backwardness of less developed regions. To decrease these gaps the EU regional policy has been designed, the aim of which is the social and economic progress. This policy is financed from the structural funds which are based on the principles of programming, concentration, partnership and complementarity. In 2004-2006 Lithuania assimilated the structural support according to the Single Programming Document (SPD) for 2004-2006 and its Annex. This support and the support for the next programming period have to contribute to a faster implementation of the Lisbon strategy which will facilitate becoming "the world's most dynamic, competitive knowledge-based economy". However, as the research of macroeconomic indexes shows, the measures and actions of the implemented regional policy do not make a major impact on the country's progress and Lithuania still significantly lags behind the average of EU countries (the progress research of EU countries shows that Lithuania is in the $20^{\text {th }}$ position among 25 countries and having assessed the progress in two years it is in the $12^{\text {th }}$ position - the progress indicator has increased by 0,26 points, whereas some new member states have achieved a greater progress, e.g. Slovakia - by 0,5 points and the Czech Republic $-0,38$ points).

The objective of this work is to assess, whether the EU regional policy is implemented in Lithuania and the policy's financial instruments are targeted at those priority sectors which make the greatest impact on the country's progress. The research object is the use of the EU structural support and its impact on the progress of 


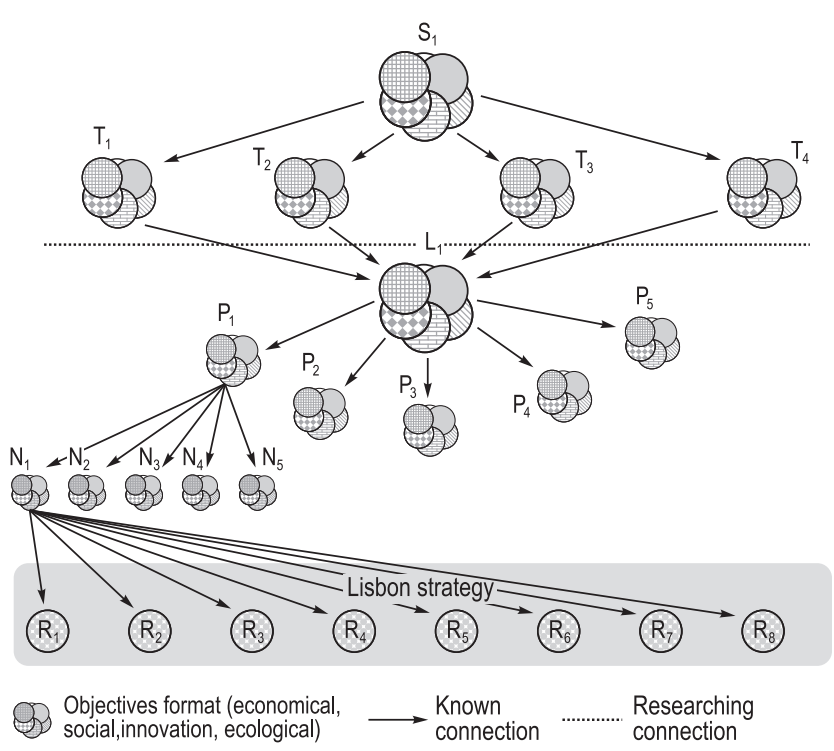

Fig 1. Structure of "molecule" of development objectives and relations with progress indexes of Lisbon strategy: $\mathrm{S}_{1}$ - goal of EU regional policy, $\mathrm{T}_{1}, \ldots, \mathrm{T}_{4}$ - objectives of EU structural funds, $\mathrm{L}_{1}-$ goal of Single Programming Document (SPD) for Lithuania for 2004-2006, $\mathrm{P}_{1}, \ldots, \mathrm{P}_{5}$ - objectives of SPD financing strategies (priorities), $\mathrm{N}_{1}, \ldots, \mathrm{N}_{5}$ - objectives of measures for separate priority, $\mathrm{R}_{1}, \ldots, \mathrm{R}_{8}$ - progress indexes of Lisbon strategy implementation

the Lithuanian economy. The research methods are the multiannual experience of the authors in the field of handling the EU support, the methods of systematic, comparative, logical and documentary analysis of research literature and the multicriterial model of assessing EU countries' progress.

\section{EU Regional policy, structural funds and their tasks}

In order to assess the impact of the EU structural support on the country's progress, first of all, it is important to understand the very tasks of the EU regional policy, assigning of structural funds and the measures used to implement these tasks in Lithuania. The goals of the EU regional policy, EU structural funds, the Single Programming Document (SPD) for Lithuania and its financing strategies (priorities) could be depicted as a "Molecule of Development Objectives" in which every atom of this molecule is pictured according to the existing structure and demonstrates complex relations between these atoms. Fig 1 also displays the relation between the EU support use strategies planned by Lithuania and the indexes of the Lisbon strategy implementation progress. With reference to this scheme the authors of the article try to reveal the expedience of using the EU structural support in Lithuania and the impact of this support on the country's progress.
EU Regional policy and its objectives. EU regional (Latin: regio - country, land, vicinity) policy is the second largest EU policy in terms of budget (after the EU Common Agricultural Policy). The regional policy budget accounted for 213 billion Lt in 2000-2006. The EU regional policy emerged due to a huge gap between the richest and the poorest EU states (social and economic justification of the EU regional policy). For example, in 2000 the difference in GDP per capita between $10 \%$ of the richest and the poorest EU-15 member states regions was 2,6 times. In 2004 after new membership accession this difference increased by nearly 4,5\% and in 2007 after Bulgaria and Romania joined - even up to 6 times [1].

The goal of the EU regional policy is a consistent reduction of social and economic differences between regions and promotion of even development of the entire EU (in Fig 1 this goal is indicated as $S_{1}$ ). The overall goal of the EU regional policy is social and economic cohesion.

The EU regional policy is addressed to: a) supporting economic development in EU regions, establishing of required long-term development conditions (long-term objectives); b) formation of infrastructure following social, economic and environmental requirements (material and non-material investments in long-term assets, human resources); c) reduction of differences in living, economic, cultural and educational situation between the EU regions [2].

The EU Regional Policy is characteristic of the combination of these main features: i) regionalization (based on the central authorities and management "from top to bottom"); ii) regionalism (based on management method "from bottom to top" as well as territorial integration); iii) decentralization of regional authorities (internal redistribution of national tasks for regional subdivisions) [2].

Structural funds. To implement the objectives of the EU regional policy EU member states receive financial support from four structural funds and a separate Cohesion Fund. The general objectives of the structural funds are as follows: a) support to development of poorer regions with the main focus on investments in production sector and even development; b) support to economic and social restructuring problem fields; c) support to education, upgrade of skills, training and retraining.

The objective of the EU Regional Development is to reduce regional differences between regions and to promote sustainable development. The objective of the 
European Social Fund is support to human resources and promotion of employment. The objective of the European Agricultural Guidance and Guarantee Fund is support to the Common Agricultural Policy and development of agricultural structures. The objective of the Financial Instruments for Fisheries Guidance is a sustainable management of resources and creation of competitive structures (Objectives of the EU Structural Funds are indicated as $T_{1}, T_{2}, T_{3}, T_{4}$ in Fig 1).

Objectives of EU support use in Lithuania. In 20042006 the EU structural support was used according to the Single Programming Document (SPD). The Single Programming Document is a general document for planning investments allotted by the EU to a country. The document prescribes an appropriate development strategy, it presents description of priorities and tasks and a preliminary financial plan. It was planned that with the help of this Programming Document the structural fund investments will help improving the economic-social state of the country and enable Lithuania to use favourable GDP growth indicators and the progress which was directed at achieving macroeconomic stability by developing the necessary structural reforms.

The main goal of Lithuanian SPD for 2004-2006 was to increase preconditions of the long-term competitiveness development of the national economy, accelerate transition to knowledge economy which is characteristic of the growth of GDP and a high indicator of population employment, strengthen the development of knowledge economy which determines a higher level of life and wellbeing of all Lithuanian population [3]. In Fig 1 the main goal of SPD is indicated as $\mathrm{L}_{1}$, SPD priority objectives $-\mathrm{P}_{1}, \mathrm{P}_{2}, \mathrm{P}_{3}, \mathrm{P}_{4}, \mathrm{P}_{5}$ and measure objectives of an individual priority $-\mathrm{N}_{1}, \mathrm{~N}_{2}, \mathrm{~N}_{3}$ ). A more detailed description of SBPD financing strategies (priorities) and their measures are illustrated in Table 4.

The objectives of the EU support use and their implementation actions strengthen each other, promote competitiveness of the Lithuanian economy, increase of employment, wide economic and social integration, thus, they are harmonized with the EU regional development objectives.

The Lithuanian strategy of using the EU structural support for 2007-2013 is based on and continues coherently the strategic vision formed by the Lithuanian SPD for 2004-2006 that in 2015 Lithuania will reach the social - economic level of some old EU member states. The goal of using the EU structural support for Lithuania in 2007-2013 is a fast improvement of investing, working and living conditions in Lithuania so as to achieve the benefits of economy growth for all Lithuanian population $[1,4]$.
The objectives of using the EU structural support for 2007-2013 will be reached by several priority directions which will hopefully give the maximum effect and allow speeding up of the Lithuanian economy development (compared with 2004-2006 these priorities decreased in number as the support to rural development and agriculture will be distributed according to another programming document). Priority directions of the EU structural support use in 2007-2013 are as follows: i) productive human resources for knowledge society; ii) competitive economy; iii) life quality and cohesion. While preparing the EU structural support use strategy for 2007-2013 the EU horizontal level priorities, needs of different public policies, financing of application of the EU legal provisions and the principle of partnership are followed as well as the results and lessons of programmes for 2004-2006 are taken into account.

Thus, the EU regional policy is distinguished for the ambition to reduce social and economic differences between separate regions and promote even progress of the entire EU. The main instrument used in regional policy development is structural funds, the general objectives of which are the support to the development of poorer regions with the main focus on investments in production sector and even development, support to economic and social restructuring in problem fields and support to education, upgrade of skills, training and retraining. In 2004-2006 in Lithuania the EU structural support was used with reference to the Single Programming Document, the purpose of which was to increase preconditions of the long-term competitiveness development of the national economy, accelerate transition to knowledge economy and strengthen its development which determines a higher level of living and wellbeing of all Lithuanian population. The Lithuanian strategy of using the EU structural support for 2007-2013 is based on the strategic vision that in 2015 Lithuania will reach the level of social and economic development of some old EU member states.

Priority directions of the EU structural support use in 2007-2013 are productive human resources for knowledge society, competitive economy and living quality and cohesion. With the help of the support from the EU structural support funds Lithuania anticipates establishing strong, competitive economy, training qualified labour force and promoting social and economic cohesion at the same time. However, the question is, if Lithuania chose those priorities of the EU support use for 2004-2006 and 2007-2013 which would enable reaching the planned declaratory objectives and have the greatest impact on the country's progress. Three years have passed since the beginning of the EU 
structural support assimilation but there is no major progress in the country (Estonia, Slovenia and Slovakia had similar starting positions but now are significantly ahead by separate progress indexes leaving Lithuania behind together with the remaining EU outsiders Poland and Latvia). Therefore, the article continues trying to answer the questions, if the Lithuanian support measures for 2004-2006 are harmonized with the Lisbon strategy and, whether these measures have impact on the country's progress.

\section{Lisbon strategy and Lithuania's progress in reaching its goals}

Lisbon Strategy. The Council of the European Leaders approved the Lisbon Strategy in 2000 and Lithuania as the EU member state must reach the long-term goal of the EU to become "the world's most dynamic, competitive knowledge-based economy" by speeding up technological progress, creating a knowledge society, implementing necessary economic reforms and decreasing social disjuncture by 2010 . The integrated Lisbon strategy guidelines are implemented by realizing the guidelines of common economic policy and employment strategy and each EU member state prepares a national reform programme additionally which presents specific measures ensuring the economic growth and the overall progress of the country. The Lisbon strategy implementation consists of 24 Guidelines (such as guaranteeing the economic stability for sustainable growth; safeguarding economic and budgetary sustainability, a prerequisite for more jobs; promotion of an efficient allocation of resources, which is geared to growth and jobs; strengthening the consistency of macroeconomic, structural and employment policies; increasing and improving investments in research and development, in particular in the private sector; facilitating all forms of innovation, etc.).

The National (Lithuanian) Lisbon Strategy Implementation Programme provides for the basic goal of the economic strategy - to minimize the backwardness of economic development levels in comparison with the average of all of the EU countries. This goal is being implemented via four major activity directions - the macroeconomic stability, structural labour market reforms, encouraging competitiveness and ensuring stability of the financial sector (this will ensure an even rate of real convergence with the EU States and a stable macroeconomic environment). The strategy preparation process for the use of structural support by Lithuania in 2007-2013 was harmonized with the priorities, objectives, tasks and measures of the Lisbon strategy implementation which need the support of structural
EU funds to be implemented. It is planned to use a part of structural support of 2007-2013 for the implementation objectives of the Lisbon strategy. The following priority directions will be financed: research and technology development, innovations and business; information society; transport; environmental protection and risk prevention; improvement of adaptability of workers and enterprises, increasing possibilities of employment and maintaining on labour market, etc. It is planned that somewhat more than a half of all Community support for the years 2007-2013 will be used for the implementation of the Lisbon strategy objectives. A conclusion can be made that about a half of the investment activities financed from the EU structural support will not contribute to the implementation of the Lisbon strategy and will not have direct influence on the country's progress.

Research of EU countries' progress. The European Commission announces the list of EU countries' progress reforms in implementing the Lisbon strategy. The methodology of this research is as follows: the generalized progress index is calculated by 8 subindexes, each of which is composed of additional criteria. The information (criteria values) is taken from the two main sources: a) the values of quantitative subindexes are taken from statistical databases (EUROSTAT, etc.); b) the values of qualitative subindexes are taken from the World Economic Executive Opinion Survey (EOS) in which the world business leaders from over 100 countries submit their opinion on different indexes the quantitative values of which cannot be identified (e.g., quality of education system, etc.). The last EOS Report was prepared in the spring of 2006.

The subindex values are taken while evaluating their significance (weight) coefficient in different categories. The qualitative subindexes are assessed under a mark system in which fixed mark values range from 1 to 7 ( 1 - minimum value, 7 - maximum value). The values of different subindex categories are added and then divided by the total number of the subindex groups (in such way the mean generalized progress index $\mathrm{R}$ is achieved).

$R=\sum_{i=1}^{8} R_{i} / 8$.

The analogical methodology of progress assessment was implemented in 2004 and 2006, therefore it is easy to compare the results obtained in different years.

Table 1 presents the composition of the analysed progress subindexes with their significances (each sub index accounts for $1 / 8$ of the total generalized index $\mathrm{R}$ and the value of each subindex consists of quantita- 
tive and qualitative criteria, the significance of which is presented in Table 1).

In the research of 2004 Lithuania was in the $7^{\text {th }}$ position with 4,05 marks among potential new countries $\left(21^{\text {st }}\right.$ position in the total list of all EU member states and new potential members). The greatest Lithuania's progress in the research was observed according to the subindexes of Network Industries and Financial Services (4,67 and 4,51 marks, respectively). The small- est progress was achieved in Information Society and Innovation Development sectors (only 3,36 and 3,57 marks, respectively).

In the research of 2006 Lithuania takes the $20^{\text {th }}$ position. Lithuania is advised to strengthen the system of scientific research and development, and to increase the state expenditure in this field significantly. It is also necessary for Lithuania to put additional efforts in order to increase the supply of qualified labour force,

Table 1. Groups of progress subindexes used in research and their weights

\begin{tabular}{|c|c|}
\hline Subindexes & Weight \\
\hline Information Society $\left(R_{1}\right)$ & $1 / 8$ \\
\hline $\begin{array}{l}\text { Survey (EOS) data (information and communication technologies; government programmes promoting } \\
\text { the use of ICT; laws relating to the use of information technology; etc.) }\end{array}$ & $2 / 3$ \\
\hline Hard data (internet users per 10.000 inhabitants; personal computers per 100 inhabitants) & $1 / 3$ \\
\hline Innovation and Research and Development $\left(\mathbf{R}_{2}\right)$ & 1/8 \\
\hline $\begin{array}{l}\text { Survey (EOS) data (your country's level of technological readiness; scientific research institutions in } \\
\text { country; business collaboration with local universities, etc.) }\end{array}$ & $2 / 3$ \\
\hline Hard data (utility patents granted per million population; gross tertiary enrolment rate) & $1 / 3$ \\
\hline Liberalization $\left(\mathbf{R}_{3}\right)$ & $1 / 8$ \\
\hline $\begin{array}{l}\text { Survey (EOS) data (competition in the local market, local suppliers in your country, the quality of local } \\
\text { suppliers, standards on product/service quality, energy and other regulations, antimonopoly policy, etc.)) }\end{array}$ & $3 / 3$ \\
\hline Hard data (none) & - \\
\hline Network Industries $\left(\mathbf{R}_{\mathbf{4}}\right)$ & $1 / 8$ \\
\hline $\begin{array}{l}\text { Survey (EOS) data (new telephone lines, mobile or cellular telephones, general infrastructure, roads and } \\
\text { railroads, passenger air transport, the quality of electricity supply, etc) }\end{array}$ & $3 / 4$ \\
\hline Hard data (mobile connection per 100 inhabitants, telephone lines per 100 inhabitants) & $1 / 4$ \\
\hline Financial Services $\left(\mathbf{R}_{5}\right)$ & $1 / 8$ \\
\hline $\begin{array}{l}\text { Survey (EOS) data (protection of proprietary rights, know-how level of finance market, security level of } \\
\text { banks, activeness of stock-market, level of financial audit and financial accountability, etc.) }\end{array}$ & $3 / 3$ \\
\hline Hard data (non-existent) & - \\
\hline Enterprise $\left(\mathbf{R}_{6}\right)$ & $1 / 8$ \\
\hline $\begin{array}{l}\text { Survey (EOS) data (business initiation procedure, conditions of obtaining bank credit, conformity to set } \\
\text { standards, country's tax level, level of business informativeness, etc.) }\end{array}$ & $1 / 2$ \\
\hline $\begin{array}{l}\text { Hard data (number of administrative procedures when starting business, number of days required for } \\
\text { starting business, etc.) }\end{array}$ & $1 / 2$ \\
\hline Social Inclusion $\left(\mathbf{R}_{7}\right)$ & $1 / 8$ \\
\hline $\begin{array}{l}\text { Survey (EOS) data (method of paying employees, conditions of equal oportunities, children protection, } \\
\text { adaptability of education system to market needs, quality of education system, level of business investments } \\
\text { in education, government efforts to decrease poverty and income unevenness, etc.) }\end{array}$ & $8 / 9$ \\
\hline Hard data (level of unemployment) & $1 / 9$ \\
\hline Sustainable Development $\left(\mathbf{R}_{8}\right)$ & $1 / 8$ \\
\hline $\begin{array}{l}\text { Survey (EOS) data (stringency level of environmental regulation, consistency of environmental regulation, } \\
\text { environmental policy of enterprises processing natural resources) }\end{array}$ & $3 / 3$ \\
\hline Hard data (non-existent) & - \\
\hline
\end{tabular}


promote regional movement of employees and further education of the oldish employees. The results of the Lithuanian progress research in 2004 and 2006 are presented in Table 2.

As it can be seen from Table 2 the greatest change was achieved in the sectors of Information Society and Financial Services.

Although the changes in the development of Information Society can be observed, however, Lithuania is still among the outsiders $\left(18^{\text {th }}\right.$ position among EU-25 countries) compared with the EU countries' average. Both the abundant support from the EU structural funds and the implemented active state programme of the information society development did not help to achieve a marked progress. As a comparison Estonia could be mentioned, which was in the $5^{\text {th }}$ position among all EU-25 countries despite the fact that it had been in the similar position as Lithuania after the restitution of independence.
The least noticeable progress was achieved in Liberalization and Sustainable Development sectors although the most attention had been paid to these sectors during the EU structural support period of 2004-2006 (to increase competitiveness and to implement environmental measures).

The most advanced countries are Denmark, Finland and Sweden. Ireland belongs to the three best countries in creating the most favourable business environment according to business establishment and credit obtaining conditions. Lithuania is significantly behind another Baltic country Estonia which was in the $12^{\text {th }}$ position under the general progress research. The third Lithuanian neighbour Latvia was in the $22^{\text {nd }}$ position.

As it can be seen from Table 3 the Lithuanian progress indexes are considerably lower compared to the average of EU countries and much more below the average of the USA and Eastern Asian countries (see Fig 2). Lithuania is best assessed by separate business devel-

Table 2. Lithuanian progress research results in 2004 and 2006

\begin{tabular}{|l|c|c|c|}
\hline \multicolumn{1}{|c|}{ Subindexes } & Score 2004 & Score 2006 & Variation \\
\hline Information society $\mathrm{R}_{1}$ & 3,36 & 3,97 & $+0,61$ \\
\hline Innovation and R\&D $\mathrm{R}_{2}$ & 3,57 & 3,69 & $+0,12$ \\
\hline Liberalization $\mathrm{R}_{3}$ & 4,10 & 4,18 & $+0,08$ \\
\hline Network industries $\mathrm{R}_{4}$ & 4,51 & 4,86 & $+0,35$ \\
\hline Financial services $\mathrm{R}_{5}$ & 4,67 & 4,96 & $+0,29$ \\
\hline Enterprise $\mathrm{R}_{6}$ & 4,38 & 4,57 & $+0,19$ \\
\hline Social inclusion $\mathrm{R}_{7}$ & 3,69 & 3,95 & $+0,26$ \\
\hline Sustainable development $\mathrm{R}_{8}$ & 4,17 & 4,26 & $+0,09$ \\
\hline Final Index (R) & $\mathbf{4 , 0 6}$ & $\mathbf{4 , 3 1}$ & $+\mathbf{0 , 2 5}$ \\
\hline
\end{tabular}
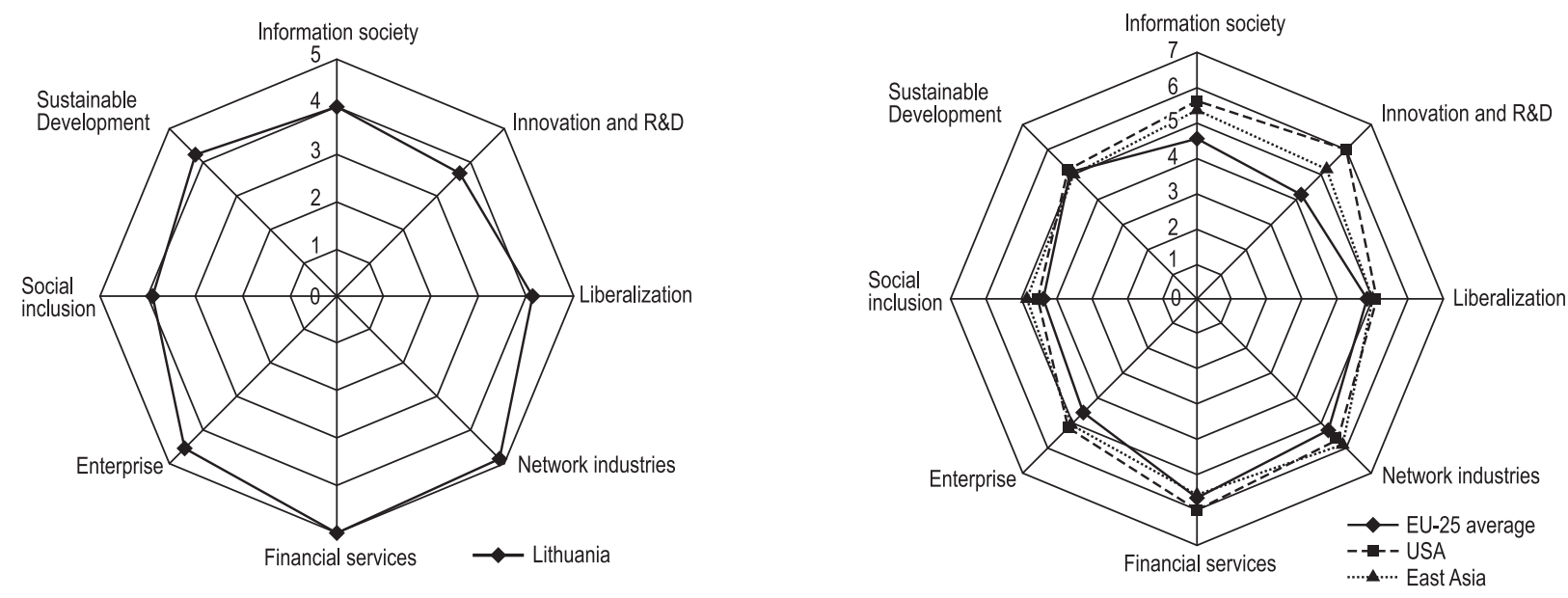

Fig 2. Analysis of progress indexes of Lithuania, EU, USA and Eastern Asian countries 
Table 3. EU countries' progress indicators

\begin{tabular}{|c|c|c|c|c|c|c|}
\hline & & Score 2004 & Score 2006 & Variation & Rank by progress & Final rank 2006 \\
\hline & Denmark & 5,63 & 5,76 & 0,13 & 17 & 1 \\
\hline 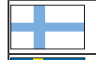 & Finland & 5,8 & 5,74 & $-0,06$ & 22 & 2 \\
\hline 8 & Sweden & 5,62 & 5,74 & 0,12 & 18 & 3 \\
\hline & Netherlands & 5,21 & 5,59 & 0,38 & 4 & 4 \\
\hline & Germany & 5,18 & 5,53 & 0,35 & 7 & 5 \\
\hline YN & United Kingdom & 5,3 & 5,5 & 0,2 & 12 & 6 \\
\hline & Austria & 4,94 & 5,3 & 0,36 & 6 & 7 \\
\hline & Luxemburg & 5,14 & 5,29 & 0,15 & 16 & 8 \\
\hline & France & 5,03 & 5,21 & 0,18 & 14 & 9 \\
\hline & Belgium & 4,88 & 5,15 & 0,27 & 10 & 10 \\
\hline & Ireland & 4,69 & 5,09 & 0,4 & 2 & 11 \\
\hline & Estonia & 4,64 & 4,93 & 0,29 & 8 & 12 \\
\hline (9) & Portugal & 4,25 & 4,64 & 0,39 & 3 & 13 \\
\hline & Czech Republic & 4,16 & 4,53 & 0,37 & 5 & 14 \\
\hline 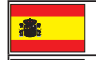 & Spain & 4,47 & 4,49 & 0,02 & 21 & 15 \\
\hline & Slovenia & 4,36 & 4,44 & 0,08 & 19 & 16 \\
\hline & Hungary & 4,12 & 4,4 & 0,28 & 9 & 17 \\
\hline 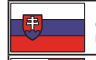 & Slovak Republic & 3,89 & 4,38 & 0,49 & 1 & 18 \\
\hline & Malta & 4,2 & 4,38 & 0,18 & 14 & 19 \\
\hline & Lithuania & 4,05 & 4,31 & 0,26 & 11 & 20 \\
\hline$\overline{6}$ & Cyprus & $*$ & 4,28 & $*$ & $*$ & 21 \\
\hline & Latvia & 4,34 & 4,25 & $-0,09$ & 23 & 22 \\
\hline E & Greece & 4,0 & 4,19 & 0,19 & 13 & 23 \\
\hline & Italy & 4,38 & 4,17 & $-0,21$ & 24 & 24 \\
\hline & Poland & 3,68 & 3,76 & 0,08 & 20 & 25 \\
\hline
\end{tabular}

opment criteria (Lithuania achieved 4,57 marks out of 7 and was positioned $13^{\text {th }}$ among all $25 \mathrm{EU}$ countries). This index was assessed by the following criteria: the procedure of establishing a new enterprise; a possibility to obtain a bank loan by only submitting a business plan; the number of procedures required to start business; the number of days necessary to establish an enterprise; the country's tax level; and the number of procedures required to arrange a contract, etc.

The worst situation in Lithuania according to the analysed subindexes is related to the Liberalization subindex $\left(4,18\right.$ marks achieved and the $24^{\text {th }}$ position in EU-25). The progress is not visible in Lithuania in the fields of Social Inclusion and Sustainable Development (20 $0^{\text {th }}$ and $21^{\text {st }}$ positions in EU-25, respectively) as well.

There is no major progress in Lithuania in employees' efficiency, payment to employees, equal opportunities, lifelong learning, education, improvement of researches and other spheres.

Compared to other EU countries Lithuania is also lagging behind in the field of innovation development due to prevailing orientation of economic entities towards traditional technologies and markets.

As we can see from the research of the Lithuanian progress in implementing the Lisbon strategy, Lithuania's greatest progress in 2004-2006 was in the sphere of Information Society $\left(\mathrm{R}_{1}\right)$, though it did not exceed 4,0 mark threshold. Compared with 2004, out of the least advanced fields in 2006 only the Social sector developed faster and rapid growth of emigration and the decreasing average of unemployment at the same time had the greatest impact on that. Therefore, it can be stated that there was no essential break-through in economy development in 2004-2006 (compared to other ES-25 countries), in spite of the fact that the 
country's economy was growing fast and Lithuania was allotted considerable support from the EU structural funds to reduce discrepancies.

\section{Harmonization of EU structural support use with Lisbon strategy and impact on country's progress}

It is early days yet to speak about the impact of the EU structural support on the Lithuanian economy development as a part of the projects are being implemented at the moment and only slightly more than 50 percent of the support to separate sectors for the period of 2004 2006 has been allowed.

However, the country's progress research showed that individual economy development sectors do not achieve planned results and do not contribute to the overall economy development though their financing is substantial. Therefore, it is vital to reconsider, if the EU structural support has been targeted on the sectors (right priorities chosen), which determine fast economy progress and a smaller scale of unevenness among individual EU countries.

This research could be an impulse for further investigations of the efficiency in using the EU structural support.

In carrying out this research priority objectives of SPD for Lithuania for 2004-2006 were analysed (The objectives of SPD for 2004-2006 were chosen in order to give a detailed description of the situation and a possible impact on progress indexes, as programming documents for 2007-2013 are still under preparation, they can be changed by the European Commission and specific investment directions are not clearly known. In the coming period the priority directions will remain similar, therefore, the research results should be similar). The research has also established, if the objectives of these priorities are harmonized with the national implementation programme of the Lisbon strategy (three types of assessment are possible: a) fully harmonized (actions correspond to the programme objectives, measures and resources are provided for to implement these actions, institutional support is provided for); b) partly harmonized (actions partly (indirectly) contribute to the implementation of the programme objectives); c) not harmonized (actions do not correspond to the national programme objectives)). After that, it is established how much influence the priority actions provided for will have on the analysed progress subindexes $R_{1}$, $R_{2}, \ldots R_{8}$. The impact of these actions on the progress subindexes is assessed in marks as well (1 mark - minimum impact, 5 marks - maximum impact). This impact was assessed taking into account the following criteria: the nature of actions (a capital grant of income grant), the size of the group, the support budget for the period, support administration and payment, the impact on the overall country's development, the amount of impact of separate actions on the progress subindexes (e.g., Measure 3.4 of SPD has impact on 3 progress subindexes but its impact is little - e.g., the development of information services is supported but support payment for this activity is notably minimal and the impact on progress subindexes is equal to zero).

The results achieved during the research on expedience of the EU structural support and its impact on the country's progress are presented in Table 4.

It can be seen from the research results given above that about 70 percent of the actions using the EU support in 2004-2006 correspond to the measures of the national programme for implementing the Lisbon strategy. The greatest potential of contributing to the implementation of this programme is related to the measures of SPD Priority 2 „Human Resources Development". At the beginning of accepting applications the applicants applied rather unwillingly under these measures, however, later even some competition was observed in certain branches, but it is early to decide on the efficiency of support under these measures as due to the lack of administrative capabilities the support is allotted very heavily and the expected effect can be smaller than anticipated.

The weakest contribution to the measures of the national programme for implementing the Lisbon strategy is related to the measures of Priority 1 and 4 as, e.g., in this programme very little attention is paid to agribusiness and rural development sector and the measures of SPD Priority 4, in fact, only indirectly contribute to the implementation of the Lisbon strategy.

The greatest impact on the progress indexes is made by measures $2.5 ; 3.1 ; 3.2 ; 3.4 ; 4.1 ; 4.3$ and 4.4 of the Lithuanian SPD for 2004-2006.

They finance the activities of increasing competitiveness, human resources and social inclusion, development of information technologies and introduction of new technologies (innovations). The least impact on the progress indexes is made by those SPD measures which are oriented to one particular activity (e.g., measure 4.6. was mainly targeted at skill improvement (however, the support reached the consultants but not the very community members) and some approved pilot strategies which will not have any more significant impact on community development). 


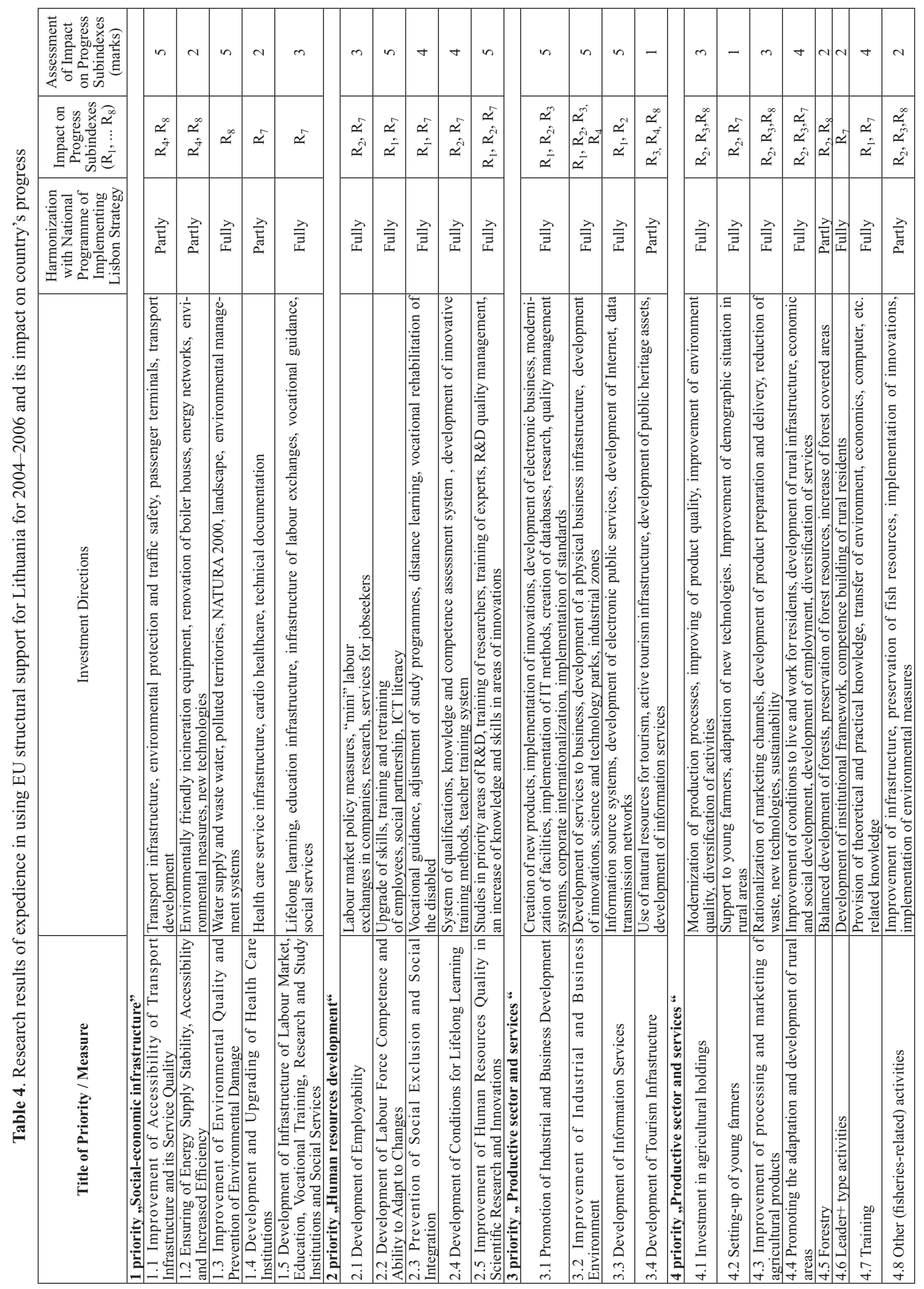


In summary it can be stated that Lithuania benefited from the substantial EU structural support in 2004-2006 allocated for decreasing economic, social, innovative, environmental and other discrepancies. The research made showed that two thirds of the EU support distribution measures (in accordance with the Single Programming Document) follow the objectives and actions of the national programme for implementing the Lisbon strategy, however, few of these measures have a complex impact on the progress indexes. The least impact on the country's economy is made by the measures oriented to "narrow" sectors of activities (e.g., healthcare, agriculture, etc.). However, although these sectors do not bear a significant impact on the progress, they are usually sectors of "political will" and they must also be developed with the help of the EU structural support.

While preparing the programmes for 2007-2013 and coordinating them with the EU Commission a better harmonization of the EU support use measures with the national programme for implementing the Lisbon strategy is necessary, and the measures have to be implemented in a complex manner, i.e., both economic - social and innovations related, environmental and other objectives of the economy development have to be achieved (e.g., in agribusiness sector both the projects solely increasing productivity of an economy entity and those also increasing possibilities to export produce, create new workplaces, introduce innovations and contribute to the implementation of environmental, hygienic, veterinary and other standards have to be supported). Only in such case the Lithuanian progress will be fast and the discrepancies compared to the EU countries will not be so huge and obvious, and the benefit of economy growing will reach all citizens of Lithuania.

The material of the research carried out could be applied in more detailed investigations so that to establish the expedience of the EU structural support and its impact on different economic-social indexes.

\section{Conclusions}

The analysis of the peculiarities of Lithuanian and the EU countries' economy development, the review of the measures applied for decreasing discrepancies and the assessment of the EU countries' progress indexes and the impact of the actions of using the EU structural support for Lithuania on these indexes suggest the following formulation of the article conclusions:

1. The research of the Lithuanian and the EU countries' main economic, social, environmental and other indexes show that Lithuania is still markedly below the EU countries' average, and EUROSTAT forecasts show that in 2008 this backwardness will not be reduced substantially. To decrease these dicrepancies the EU allots Lithuania the structural support which ensures a faster development and progress of less developed regions.

2. The EU structural support for Lithuania in 2004-2006 was distributed through the Single Programming Document. The influence of this support on the country's economy development is felt now already (a greater impact will be felt from 2008 after the finalization of the support assimilation), however, it is not sufficient for a rapid progress of the country. Lithuania is only in the $20^{\text {th }}$ position among all EU countries according to the generalized progress index, whereas Estonia is in the $12^{\text {th }}$ position considering that both countries had similar starting positions. The Lithuanian progress is least felt in the sectors of market liberalization, sustainable development and social inclusion.

3. The carried out research of the use of the EU support and its impact on the country's progress suggests that about two thirds of the measures follow the national programme of implementing the Lisbon strategy, however, few indicators have a complex influence on the progress indexes. For example, none of the measures has influence on the Enterprise group indexes, though they are indexes influencing attraction of investments to our country directly. The greatest impact on the progress indicators is made by all measures of capital (investment) grants and the measures of human resources development.

4. While preparing the programmes of using the EU support for 2007-2013 and coordinating them with the EU Commission a better harmonization of these support use measures with the national programme for implementing the Lisbon strategy is necessary, and the measures have to be implemented in a complex manner, i.e., both economic -social and innovations related, environmental and other objectives of the country's economy development have to be achieved and horizontal compatibility of the measures maintained. It is as well necessary to implement the actions at least partially influencing the progress subindexes of all groups (e.g., to provide soft loans for new enterprises, etc.). A greater share of the structural support for 2007-2013 should be also spared for the implementation of the Lisbon strategy objectives.

\section{References}

1. Lietuvos statistikos departamento svetainè. Available from Internet: <http://www.stat.gov.lt.>

2. ŠIDLAUSKAS, S. Lietuvos verslo galimybès pasinaudoti ES finansine parama. Verslas, vadyba ir studijos, 2003, p. 133-140. 
3. LR Vyriausybès $2005 \mathrm{~m}$. lapkričio $22 \mathrm{~d}$. nutarimas Nr. 1270 „Dèl nacionalinès Lisabonos strategijos igyvendinimo programos“. Žin., 2005, Nr. 139-5019.

4. Lietuvos 2007-2013 metų Europos Sajungos struktūrinès paramos panaudojimo strategijos projektas. Vilnius, 2006.

5. EUROSTAT statistinių duomenu bazè. Available from Internet: $<$ http://epp.eurostat.ec.europa.eu.>

6. Lietuvos 2007-2013 m. ekonomikos augimo veiksmu programos projektas. Vilnius, 2006.

7. LR Vyriausybès 2004 m. rugpjūčio 2 d. nutarimas Nr. 935 „Dèl Lietuvos 2004-2006 metų Bendrojo programavimo dokumento patvirtinimo“. Žin., 2004, Nr. 123-4486.

8. NAKROŠIS, V. Europos Sajungos regionine politika ir struktüriniu fondu valdymas. Vilnius: Eugrimas, 2003.
9. WANLIN, A. The Lisbon Scorecard VI: Will Europe's Economy Rise Again? London: Centre for European Reform, 2006.

10. World Economic Forum. Global Information Technology Report. Geneva, Switzerland, 2005.

11. World Economic Forum, Global Competitiveness Report 2006-2007. Geneva, Switzerland, 2006.

12. World Economic Forum. The Lisbon Review 2006. Measuring Europe's progress in reform. Geneva, Switzerland, 2006.

13. ГРАНБЕРГ, А. Г. Основы региональной экономики. Москва: Издательский дом ГУ ВШЭ, 2004.

14. КОВАЛЕНКО, Е. Г. Региональная экономика $и$ управление. Санкт-Петербуг: Питер, 2005. 